\title{
Detection of monokines in paraffin-embedded tissues of pigs using polyclonal antibodies
}

\author{
Francisco Javier SALguero, Tigest MeKonnen, \\ Eduardo Ruiz-VILlamor, Pedro José SÁNCHEZ-CORDÓn, \\ José Carlos GómEZ-VILlAMANDOs*
}

Departamento de Anatomía Patológica, Facultad de Veterinaria, Edificio de Sanidad Animal, Campus Universitario de Rabanales, Universidad de Córdoba, Córdoba 14014, Spain

(Received 4 January 2001; accepted 23 July 2001)

\begin{abstract}
Monokines are glycoproteins, synthesised by macrophages, which exert various effects on the organism. The most important monokines are interleukin (IL)-1 $\alpha$, IL- $1 \beta$, tumor necrosis factor (TNF)- $\alpha$ and IL-6. This paper reports on immunohistochemical techniques developed for the detection of IL- $\alpha$, IL-1 $\beta$, IL- 6 and TNF- $\alpha$ in fixed and paraffin-embedded pig tissues (spleen, lymph nodes, thymus, liver and kidney). Different fixatives (buffered formalin, acetic formalin, paraformadehyde-lysine-periodate and Bouin solution), and antigen unmasking techniques (permeabilisation with Tween 20, pronase enzymatic digestion and microwave-citrate buffer) were used. We describe different protocols for detection of monokines using polyclonal antibodies against the studied monokines. No signal was obtained with monoclonal antibodies against pig-TNF- $\alpha$ and human IL-1 $\alpha$. Bouin solution was shown to be the best fixative for immunohistochemical detection of IL-1 $\alpha$, TNF- $\alpha$, and IL-6, using permeabilisation with Tween 20 as an unmasking antigen method. Acetic formalin was shown to be the best fixative for IL-1 $\beta$ detection, not needing antigen retrieval techniques. Macrophages were identified as the main cytokine-producing cells, although other types of cells also stained positively to some cytokines. These techniques represent valuable tools for studies of the pathogenesis of viral and bacterial diseases, and of the immune system of the pigs.
\end{abstract}

pig / cytokine / polyclonal antibody / macrophage

Résumé - Détection de monokines dans des tissus de porc fixés dans la paraffine en utilisant des anticorps polyclonaux. Les monokines sont des glycoprotéines synthétisées par les macrophages, qui exercent différents effets sur l'organisme. Les monokines les plus importantes sont l'interleukine (IL)-1 $\alpha$, l'IL-1 $\beta$, le facteur de nécrose tumorale (TNF)- $\alpha$ et l'IL-6. Ce travail rapporte des techniques immunohistochimiques permettant la détection de monokines dans les tissus du porc fixés dans la paraffine (rate, nodule lymphatique, thymus, foie et rein). Différents fixateurs (formol tamponné, formol acétique, paraformaldéhyde-lysine-periodate et la solution de Bouin), et des techniques pour

* Correspondence and reprints

Tel.: (34) 957 218162; fax: (34) 957 218847; e-mail: jcgomez@uco.es 
démasquer les antigènes (perméabilisation avec le Tween 20, digestion enzymatique avec la pronase et micro-onde avec tampon citrate) ont été utilisées. Nous avons élaboré des protocoles différents pour chaque anticorps polyclonal. Aucun signal n'a été obtenu avec les anticorps monoclonaux contre le TNF- $\alpha$ du porc et l'IL-1 $\alpha$ humaine. La solution de Bouin s'est révélée être le meilleur fixateur pour la détection immunohistochimique d'IL-1 $\alpha$, TNF- $\alpha$ et IL-6, en utilisant la perméabilisation avec le Tween 20 comme méthode pour démasquer l'antigène. Le formol acétique s'est révélé être le meilleur fixateur pour l'IL-1 $\beta$, ne nécessitant pas de techniques de récupération de l'antigène. Les macrophages ont été identifiés comme les principales cellules produisant des cytokines, bien que d'autres types cellulaires se soient aussi révélés positifs pour quelques cytokines. Ces techniques représentent un outil précieux pour étudier la pathogénie des maladies virales et bactériennes du porc et son système immunitaire.

porc / monokine / anticorps polyclonal / macrophage

\section{INTRODUCTION}

Immune system cells secrete a surprising variety of proteins that regulate the immune response by intercellular signalling. These regulatory proteins are generally termed cytokines. During recent years, there has been a dramatic increase in our knowledge of cytokines and their role in both animal and human physiology, immunology and pathology $[20,26]$.

Macrophages and monocytes are the cell types responsible for most secretion and inflammatory cytokine expression, although these proteins can be secreted by a broad spectrum of cell types [20]. In recent years, monokines, which are cytokines produced by monocyte-macrophages, have been shown to play a major role in numerous bacterial [1, 3, 23] and viral diseases [26-28] inducing and modulating the production of various clinical signs and lesions. A number of antibodies have therefore been developed for the study of monokines, although these are generally destined for Western blot, blocking or ELISA techniques. Immunohistochemistry and in situ hybridisation techniques will allow pathologists to investigate the spatial relationship between microscopic lesions and cytokine-producing cells.

This paper addresses the major monokines in terms of their proinflamma- tory action: tumor necrosis factor (TNF)- $\alpha$, interleukin (IL)-1 $\alpha$, IL-1 $\beta$ and IL-6 [19].

The best known inducer of these cytokines is the Gram-negative bacterial cell-wall lipopolysaccharide (LPS). Certain aspects of cytokine expression have been studied in animal bacterial diseases, but not so hardly in viral diseases [20], although it has been suggested that cytokines may be involved in the pathogenesis of several viral diseases including the African swine fever $[8,9,11]$, swine influenza [27], porcine respiratory coronavirus infection [26], porcine reproductive and respiratory syndrome [26], caprine arthritis-encephalitis [16], Ebola and Marburg virus infection [7], classical swine fever [10] and HIV infection [4].

Given that the pig is an ideal source for xenotransplantation, the study of the porcine immune system is of particular interest. A considerable genomic and antigenic correlation is reported between human and porcine monokines [24]. Porcine TNF- $\alpha$, interleukin- $1 \alpha$ and interleukin- $1 \beta$ show genomic homologies of $86 \%$ [21] $82 \%$ [18] and $72 \%$ [14] respectively, with the corresponding human sequences. This paper reports on the standardisation of immunohistochemical techniques to detect the expression of various monokines in paraffinembedded swine tissues, using antibodies against human and porcine monokines. 


\section{MATERIALS AND METHODS}

Five Large White $\times$ Landrace pigs from the slaughter house, each with a live weight of approximately $90 \mathrm{~kg}$ and free of lesions characteristic of parasitic and infectious diseases at slaughter, were used in the experiment. After slaughter, 3-4 mm thick tissue samples of the spleen, gastrohepatic lymph node, thymus, liver and kidney were taken and immersed in various fixatives: $10 \%$ formalin (considering $37-40 \%$ formalin as pure) buffered with phosphate-buffered saline (PBS) pH 7.2 for $24 \mathrm{~h}$; acetic formalin (20:1 of $10 \%$ formalin, glacial acetic acid) for $24 \mathrm{~h}$; paraformaldehyde-lysineperiodate (PLP) (0.01 M periodate, $0.1 \mathrm{M}$ lysine, paraformaldehyde $0.125 \%$ ) for $18 \mathrm{~h}$; and Bouin fixation solution (15:5:1 of 10\% formalin, glacial acetic acid, picric acid saturated solution in distilled water) for $18 \mathrm{~h}$. Samples fixed with the Bouin solution were rinsed 7 times in ethanol 50\%, 30 min each time, and stored in ethanol $70 \%$ until embedding. Samples fixed in PLP were placed in absolute ethanol until embedding. Samples fixed in acetic and buffered formalin were rinsed in distilled water and were routinely embedded along with samples fixed in the Bouin solution and PLP.

The avidin-biotin-peroxidase complex (ABC) technique was used. Tissue sections of about $4 \mu \mathrm{m}$ width were deparaffinised by 3 steps in xilol, $10 \mathrm{~min}$ per step, followed by two steps, $5 \mathrm{~min}$ each, in absolute ethanol. Afterwards, they were incubated with $1 \%$ hydrogen peroxide in methanol for 45 minutes to block the endogenous peroxidase activity, followed by one step of $5 \mathrm{~min}$, in $96 \%$ ethanol, $70 \%$ ethanol, distilled water and PBS pH 7.2. Different antigen retrieval or permeabilisation methods were used to test the samples in all different fixations: $0.1 \%$ pronase (Sigma Chemical Company, Poole, Dorset, UK) in PBS pH 7.2 (10 min at room temperature); microwave in $\mathrm{pH} 6.0$ citrate buffer $(5 \mathrm{~min}$ from the beginning of boiling), or $0.01 \%$ Tween 20 (Merck \& Co, Inc., WhiteHouse Station, NJ, USA) in PBS
$\mathrm{pH} 7.2$ (10 min at room temperature). After pretreatment, samples were rinsed three times in PBS pH 7.2 for 10 min each. Tissue sections were covered with $10 \%$ normal goat serum (ICN Biomedicals Inc., Aurora, Ohio, USA) in PBS pH 7.2 for $30 \mathrm{~min}$ at room temperature, before incubation with the primary antibody for $1 \mathrm{~h}$ at $37^{\circ} \mathrm{C}$. Different commercial antibodies against IL-1 $\alpha$ (Anti-human Interleukin-1 $\alpha$ Polyclonal ${ }^{\circledR}$, Endogen, Woburn MA, USA; Monoclonal mouse anti-human IL-1 $\alpha^{\circledR}$, Genzyme Diagnostics, Cambridge MA, USA), IL-1 $\beta$ (AntiHuman Interleukin- $1 \beta$ Polyclonal ${ }^{\circledR}$, Endogen), TNF- $\alpha$ (Polyclonal rabbit anti-human TNF- $\alpha$ neutralising IP- $300^{\circledR}$, Genzyme Diagnostics; Anti-pig TNF- $\alpha$ Monoclonal Antibody 4F4 ${ }^{\circledR}$, Endogen) and IL-6 (AntiHuman Interleukin-6 Polyclonal Purified Antibody ${ }^{\circledR}$, Endogen; Anti-pig Interleukin6 Purified Polyclonal ${ }^{\circledR}$, Endogen) were used with different dilutions. The ability of antihuman monokines, antibodies to detect swine monokines was successfully checked by ELISA (unpublished data). Biotinylated goat anti-rabbit secondary antibody (Vectastain ABC Kit Elite ${ }^{\circledR}$, Vector, Burlingame, CA, USA) diluted 1:200 in PBS pH 7.2 containing $10 \%$ normal goat serum was incubated for $30 \mathrm{~min}$ at room temperature, for polyclonal primary antibodies. Biotinylated goat anti-mouse secondary antibody (AntiMouse Immunoglobulins Biotin ${ }^{\circledR}$, Dako, Glostrup, Denmark) diluted 1:20 in PBS $\mathrm{pH} 7.2$ containing $10 \%$ normal goat serum was incubated for $30 \mathrm{~min}$ at room temperature, for monoclonal primary antibodies. Afterwards, the samples were incubated with the ABC (Vectastain ABC Kit Elite ${ }^{\circledR}$, Vector) for $1 \mathrm{~h}$ at room temperature in the dark. Between each step, the slides were washed 3 times for 10 min each in PBS $\mathrm{pH}$ 7.2. The chromogen $0.35 \mathrm{~g} / \mathrm{L} 3$ 3'diaminobenzidine tetrahydrochloride (DAB, Sigma) diluted in $\mathrm{pH}$ 7.6 Tris buffer containing $0.1 \%$ hydrogen peroxide was applied to the slides for $1 \mathrm{~min}$. Slides were counterstained with the Mayer haematoxylin. In negative controls, the primary 
specific antibody was replaced by PBS, non immune rabbit serum and non immune mouse serum.

\section{RESULTS}

All studied tissues (spleen, lymph nodes, thymus, liver and kidneys) displayed similar behaviour regardless of the fixatives and treatments tested: none of the monoclonal antibodies used elicited positive immunoreactivity in any tissue, whereas all the polyclonal antibodies tested, which included both anti-human monokine and anti-swine monokine antibodies, elicited a positive reaction using various fixatives (Tab. I). No positive reaction was detected in negative controls.

The tissues fixed in the Bouin solution stained positive to all antibodies except interleukin-1 $\beta$, for which positive immunostaining was obtained only in samples fixed in buffered formalin or acetic formalin. Moreover, although Bouin-fixed samples stained positive to anti-IL- $1 \alpha$, anti-TNF $\alpha$ and anti-IL-6, positive results were obtained in tissues fixed in PLP, but they showed

Table I. Treatments and antibodies used for detection of monokines in the spleen, lymph node, kidney, liver and thymus of pigs.

\begin{tabular}{|c|c|c|c|c|c|c|c|}
\hline $\begin{array}{l}\text { Fixative } \\
\text { Antigen retrieval method }\end{array}$ & $\begin{array}{l}\text { IL-1 } \alpha^{\mathrm{a}} \\
(1: 100)\end{array}$ & $\begin{array}{l}\text { TNF- } \alpha^{\mathrm{b}} \\
(1: 500)\end{array}$ & $\begin{array}{l}\text { IL-1 } \beta^{\mathrm{c}} \\
(1: 100)\end{array}$ & $\begin{array}{l}\text { hIL-6 } \\
(1: 500)\end{array}$ & $\begin{array}{l}\text { pIL6 }^{\mathrm{e}} \\
(1: 10)\end{array}$ & $\begin{array}{l}\text { Mab-h } \\
\text { IL-1 } 1 \alpha^{\mathrm{f}}\end{array}$ & $\begin{array}{l}\text { Mab-p } \\
\text { TNF- } \alpha^{\mathrm{g}}\end{array}$ \\
\hline \multicolumn{8}{|l|}{ Bouin } \\
\hline None & ++ & ++ & - & ++ & ++ & - & - \\
\hline Pronase & - & - & - & - & - & - & - \\
\hline Tween 20 & +++ & +++ & - & +++ & +++ & - & - \\
\hline Microwave-citrate buffer $\mathrm{pH} 6.0$ & $0 \quad-$ & - & - & - & - & - & - \\
\hline \multicolumn{8}{|l|}{ Acetic formalin } \\
\hline None & - & - & +++ & - & - & - & - \\
\hline Pronase & - & - & - & - & - & - & - \\
\hline Tween 20 & - & - & ++ & - & - & - & - \\
\hline Microwave-citrate buffer $\mathrm{pH} 6.0$ & 0 & - & ++ & - & - & - & - \\
\hline \multicolumn{8}{|l|}{ Buffered formalin } \\
\hline None & - & - & ++ & - & - & - & - \\
\hline Pronase & - & - & - & - & - & - & - \\
\hline Tween 20 & - & - & ++ & - & - & - & - \\
\hline Microwave-citrate buffer $\mathrm{pH} 6.0$ & $0-$ & - & + & - & - & - & - \\
\hline \multicolumn{8}{|l|}{$\begin{array}{l}\text { Paraformaldehyde-lysine- } \\
\text { periodate (PLP) }\end{array}$} \\
\hline None & + & + & - & + & + & - & - \\
\hline Pronase & - & - & - & - & - & - & - \\
\hline Tween 20 & + & + & - & + & + & - & - \\
\hline Microwave-citrate buffer $\mathrm{pH} 6.0$ & $0+$ & +++ & - & - & + & - & - \\
\hline
\end{tabular}

-: No reaction; +: positive reaction and hard background; ++: positive reaction and light background; +++: positive reaction with no background.

a Anti-human interleukin-1 $\alpha$. Polyclonal rabbit purified antibody.

${ }^{\mathrm{b}}$ Anti-human TNF- $\alpha$. Polyclonal rabbit neutralising antibody.

${ }^{c}$ Anti-human interleukin-1 $\beta$. Polyclonal rabbit purified antibody.

d Anti-human interleukin-6. Polyclonal rabbit purified antibody.

e Anti-swine interleukin-6. Polyclonal rabbit purified antibody.

${ }^{f}$ Anti-human IL-1 $\alpha$. Monoclonal mouse antibody.

g Anti-swine TNF- $\alpha$. Monoclonal mouse antibody. 
unspecific background, making the Bouin solution the best fixative for these antibodies. In the case of anti-TNF $\alpha$ antibody, PLP fixed samples showed positiveness using microwave-citrate buffer $\mathrm{pH} 6.0$ as an antigen-retrieval technique, as well as using Bouin solution as a fixative and Tween 20 as an unmasking technique (Tab. I).

Pronase treatments yielded negative results in all cases, and Tween 20 proved largely to be the treatment of choice although optimal results were obtained with microwave irradiation in a $\mathrm{pH} 6.0$ citrate buffer solution (Tab. I).

Cell counts were made in samples fixed in the Bouin solution and treated with
Tween 20 for IL-1 $\alpha$, TNF- $\alpha$ and IL-6, and in samples fixed in acetic formalin with no treatment for IL-1 $\beta$. The number of positive cells against monokines are expressed as means of the animals of the study (Tab. II).

The major immunoreactive cells were monocyte-macrophages (Fig. 1-4) although they were relatively few in number compared with studies of other authors related with different diseases. IL- $1 \alpha$ additionally elicited positive staining in neutrophils (Fig. 1), and IL-1 $\beta$ in fibroblasts. Cytokine expression was fairly uniform in all studied tissues, except in those of one pig which displayed a far greater number of cytokine-expressing cells. Histopathological

Table II. Positive cells for monokines in different organs.

\begin{tabular}{|c|c|c|c|c|c|}
\hline $\begin{array}{l}\text { Organ } \\
\quad \text { Structure } \\
\text { Fixative } \\
\text { Antigen retrieval method }\end{array}$ & $\begin{array}{c}\text { IL-1 } \alpha^{\mathrm{a}} \\
\text { Bouin } \\
\text { Tween } 20\end{array}$ & $\begin{array}{l}\text { TNF- } \alpha^{\mathrm{b}} \\
\text { Bouin } \\
\text { Tween } 20\end{array}$ & $\begin{array}{c}\text { IL-1 } \beta^{\mathrm{c}} \\
\text { Ac. Form. } \\
\text { None }\end{array}$ & $\begin{array}{c}\text { hIL-6 } \\
\text { Bouin } \\
\text { Tween } 20\end{array}$ & $\begin{array}{c}\text { PIL6e } \\
\text { Bouin } \\
\text { Tween } 20\end{array}$ \\
\hline \multicolumn{6}{|l|}{ Spleen } \\
\hline Splenic cords & ++ & ++ & ++ & ++ & ++ \\
\hline Follicles & + & + & + & + & + \\
\hline Marginal zone & +++ & ++ & ++ & ++ & ++ \\
\hline \multicolumn{6}{|l|}{ Kidney } \\
\hline Glomerulus & + & + & + & ++ & ++ \\
\hline Circulant cells & + & + & + & + & + \\
\hline Medulla & ++ & + & + & + & + \\
\hline Cortex & + & + & + & +++ & ++ \\
\hline \multicolumn{6}{|l|}{ Liver } \\
\hline Kupffer cells & + & + & + & + & + \\
\hline Portal area & ++ & + & + & + & + \\
\hline Hepatic cords & ++ & + & + & + & + \\
\hline \multicolumn{6}{|l|}{ Lymph node } \\
\hline Cortex & + & + & + & + & + \\
\hline Medulla & ++ & + & + & ++ & ++ \\
\hline \multicolumn{6}{|l|}{ Thymus } \\
\hline Cortex & + & + & + & + & + \\
\hline Medulla & + & + & + & + & + \\
\hline
\end{tabular}

The results are expressed as means among all the animals of the study $\left(+: 0-1\right.$ cells $/ \mathrm{mm}^{2} ;++: 2-5$ cells $/ \mathrm{mm}^{2} ;+++$ : $>5$ cells $/ \mathrm{mm}^{2}$ ).

a Anti-human interleukin-1 $\alpha$. Polyclonal rabbit purified antibody.

$\mathrm{b}$ Anti-human TNF- $\alpha$. Polyclonal rabbit neutralising antibody.

${ }^{\mathrm{c}}$ Anti-human interleukin-1 $\beta$. Polyclonal rabbit purified antibody.

$\mathrm{d}$ Anti-human interleukin-6. Polyclonal rabbit purified antibody.

e Anti-swine interleukin-6. Polyclonal rabbit purified antibody.

${ }^{\mathrm{f}}$ Acetic formalin. 


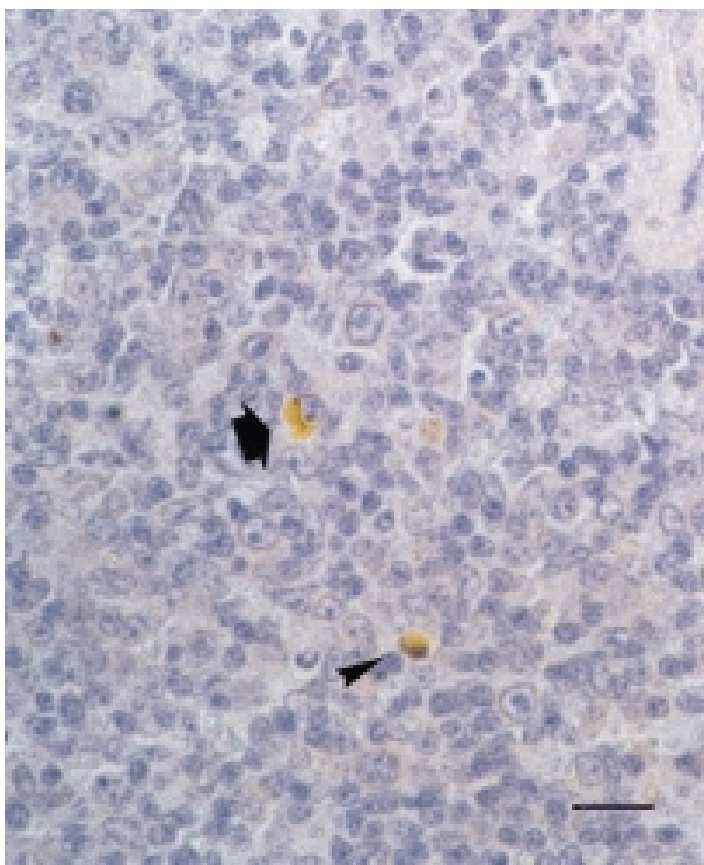

Figure 1.

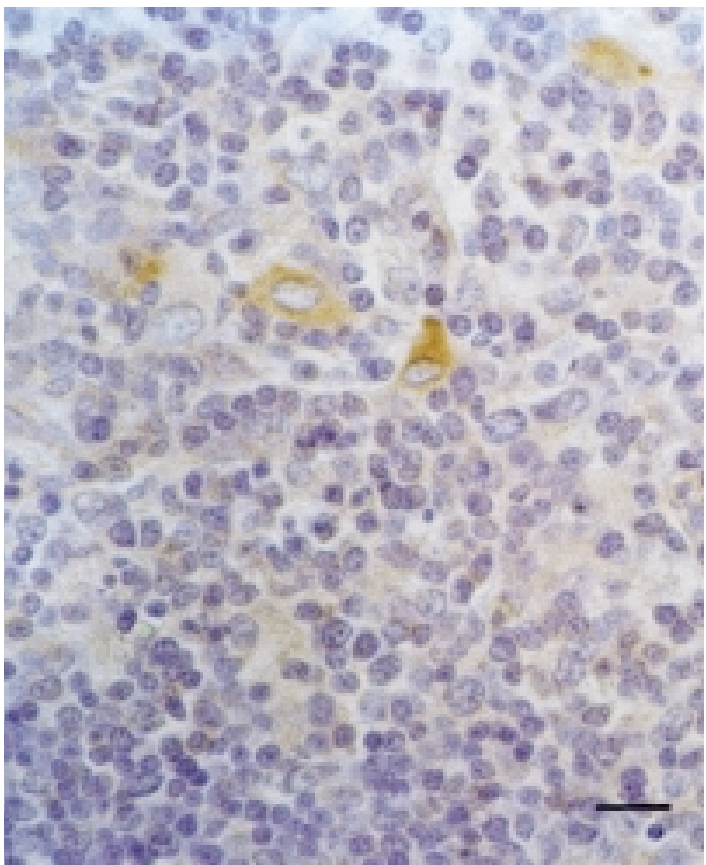

Figure 3.

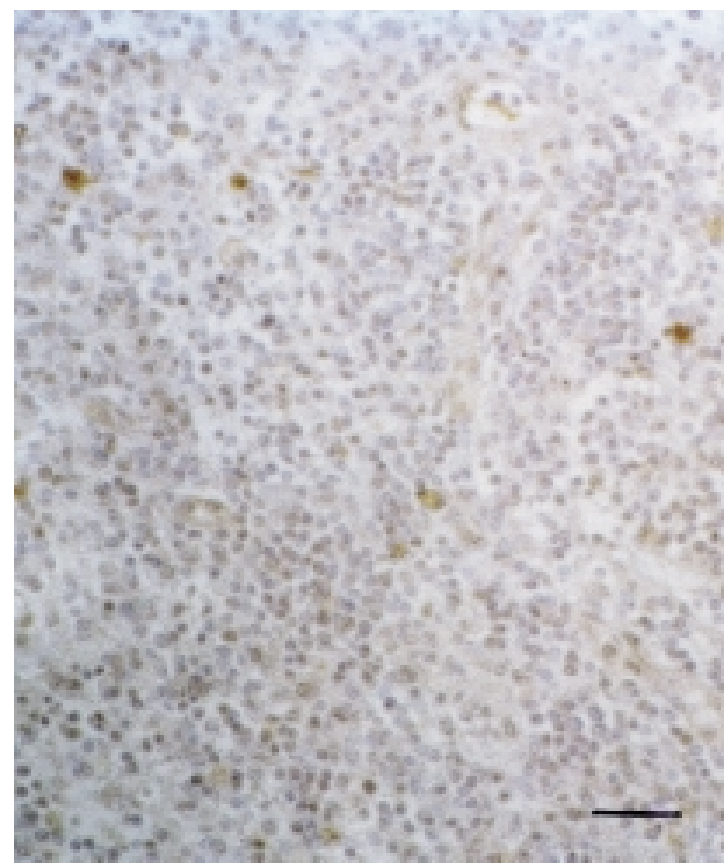

Figure 2.

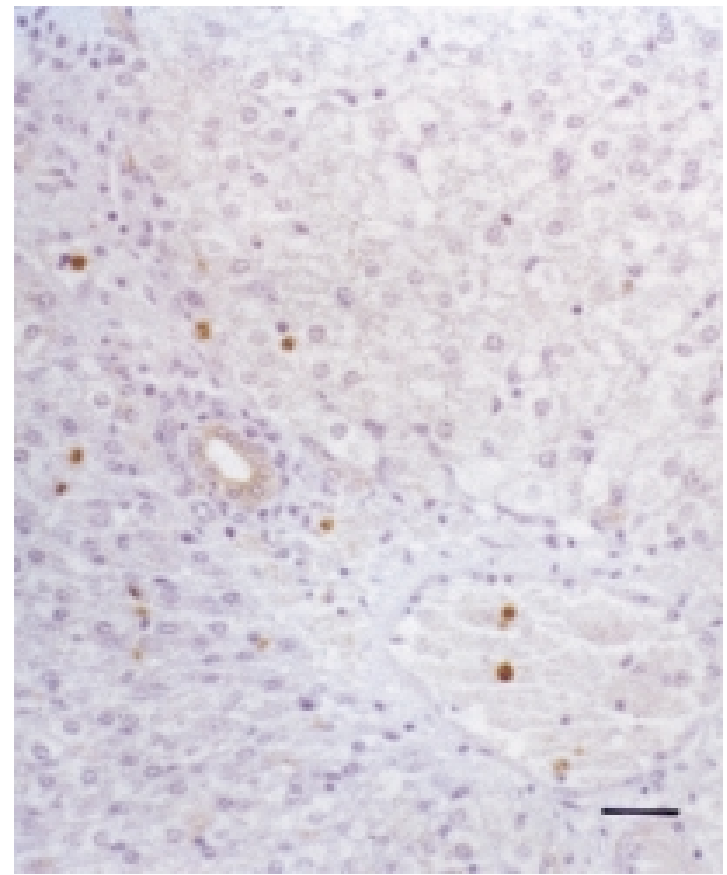

Figure 4. 
examination of tissues from this animal revealed lesions consistent with mild bacterial septicemia of undetermined etiology. The results of this animal were therefore excluded from the results.

\section{DISCUSSION}

The avidin-biotin-peroxidase complex (ABC) enables signal amplification due to affinity between avidin and biotin and many proteins including enzymes. This technique is therefore highly suitable for both diagnostic and research purposes when the target antigen is scarce or concealed [13].

In the present study, use of this technique with a variety of treatments and employing both anti-human monokine and anti-porcine monokine antibodies, enabled the detection of inflammatory cytokines in paraffinembedded swine tissues. It is therefore a valuable tool for studying the pathogenesis of swine diseases, particularly given the recent progress in xenotransplantation using swine organs, and the use of swine diseases as models for the study of a number of human and animal diseases.

The anti-human interleukin- $1 \alpha$ monoclonal antibody failed to elicit any positive reaction, since this type of antibody is likely to react with a very limited number of monokine epitopes. The cross-reaction between human and porcine monokines is high, but not total [21], and the results were perhaps unsatisfactory because the epitope(s) reacting with monoclonal antibodies were different in the swine.

The anti-porcine TNF- $\alpha$ monoclonal antibody is reported to be efficient when using ELISA and Western blot techniques [25], but its use is not recommended for immunohistochemical procedures. Other authors have reported satisfactory results when using this antibody in freeze-fixed tissue samples, in which antigen preservation is far greater than with chemical fixatives [10]. The results using fixed paraffin-embedded sections were unsatisfactory since fixation and subsequent embedding of samples for immunohistochemical examination inevitably entail a reduction in antigen preservation, and subsequent retrieval is often insufficient to allow detection [22].

The best results in the present study were obtained using Tween 20 as the permeabilising treatment for TNF- $\alpha$, IL- $1 \alpha$ and IL-6. With TNF- $\alpha$, optimal results were achieved using PLP- and Bouin-fixed samples. PLP-fixed samples required microwave treatment in a citrate buffer solution at pH 6.0 making the technique more laborious, slower and more expensive. For this reason Bouin-fixed samples are preferable.

In the immunohistochemical study, almost only monocytes and macrophages reacted positively. However these cells were relatively scarce. This was probably due to

Figure 1. Immunohistochemical detection of IL- $1 \alpha$ with a positive reaction in a macrophage (arrow) and a neutrophil (arrowhead). Lymph node of a clinically healthy pig. ABC technique. Fixation: Bouin solution. Pretreatment: permeabilisation with Tween 20. Bar: $100 \mu \mathrm{m}$.

Figure 2. Immunohistochemical detection of TNF- $\alpha$ in the spleen of a clinically healthy pig. ABC technique. Fixation: Bouin solution. Pretreatment: permeabilisation with Tween 20. Bar: $50 \mu \mathrm{m}$.

Figure 3. Immunohistochemical detection of IL-1 $\beta$ with a positive reaction in macrophages. Thymus of a clinically healthy pig. ABC technique. Fixation: acetic formalin. Pretreatment: none. Bar: $100 \mu \mathrm{m}$.

Figure 4. Immunohistochemical detection of IL-6. Circulating cells show immunopositive reaction. Liver of a clinically healthy pig. ABC technique. Fixation: Bouin solution. Pre-treatment: permeabilisation with Tween 20. Bar: $50 \mu \mathrm{m}$. 
the fact that clinically healthy animals were used. Similar findings have been reported by other authors for a number of species [5, 12]. Positive immunoreactivity to IL- $1 \beta$ was observed not only in monocyte-macrophages but also in other stromal cells including fibroblasts and muscle cells. These cells express various cytokines in normal physiological conditions and display greatly increased production in pathological conditions $[2,17]$.

The positive reaction to anti-IL- $1 \alpha$ observed systematically in numerous neutrophils may be due to two causes: either production of IL- $1 \alpha$ by neutrophils in healthy animals [6], or a non-specific reaction. The latter appears more likely since the large number of neutrophils staining positive to this cytokine, is felt to be incompatible with a healthy state. Moreover, positive immunoreactivity was quantitatively similar in healthy and sick animals.

Finally, and with regard to positive immunoreactivity against TNF- $\alpha$ in tubular epithelial cells of the kidney, Jevinkar et al. [15] report that these cells express a cytotoxic surface molecule related to TNF- $\alpha$. The presence of TNF- $\alpha$ in the cell membrane of tubular epithelial cells may enhance local bioactivity by focussing its effect on contacting cells. Increased immunostaining to TNF- $\alpha$ has been observed in swine viral diseases (unpublished data) which substantiates this hypothesis.

\section{ACKNOWLEDGEMENTS}

This work was supported by grants from Plan Andaluz de Investigación (PAI Agr-0137) and DGESIC (PB95-0558 and PB98-1033).

\section{REFERENCES}

[1] Arai K., Lee F., Miyajima A., Miyatake S., Arai N., Yokota T., Cytokines: Coordinators of immune and inflammatory responses, Annu. Rev. Biochem. 59 (1990) 783-836.
[2] Authier F.J., Mhiri C., Chazaud B., Christov C., Cherin P., Barlovatz-Meimon G., Gherardi K., Interleukin-1 expression in inflammatory myopathies: evidence of marked immunoreactivity in sarcoid granulomas and muscle fibres showing ischaemic and regenerative changes, Neuropathol. Appl. Neurobiol. 23 (1997) 132140 .

[3] Baarsch M.J., Scamurra R., Burger K., Foss D.L., Maheswaran S.K., Murtaugh M.P., Inflammattory cytokine expression in swine experimentally infected with Actinobacillus pleuropneumoniae, Infect. Immun. 63 (1995) 3587-3594.

[4] Conaldi P.G., Serra C., Dolei A., Basolo F., Falcone V., Mariani G., Speziale P., Toniolo A., Productive HIV-1 infection of human vascular endothelial cells requires cell proliferation and is stimulated by combined treatment with interleukin-1 beta plus tumor necrosis factor-alpha, J. Med. Virol. 47 (1995) 355-363.

[5] Day M.J., Expression of interleukin-1 $\beta$ interleukin- 6 and tumour necrosis factor $\alpha$ by macrophages in canine lymph nodes with mineral-associated lymphadenopathy granulomatous lymphadenitis or reactive hyperplasia, J. Comp. Pathol. 114 (1996) 31-42.

[6] Di Giovine F.S., Duff G.W., Interleukin 1: the first interleukin, Immunol. Today 11 (1990) 13-19.

[7] Geisbert T.W., Hensley L.E., Gibb T.R., Steele K.E, Jaax N.K., Jahrling P.B., Apoptosis induced in vitro and in vivo during infection by Ebola and Marburg viruses, Lab. Invest. 80 (1995) 171-186.

[8] Gómez-Villamandos J.C., Hervás J., Méndez A., Carrasco L., Martín de las Mulas J., Villeda C.J., Wilkinson P.J, Sierra M.A., Experimental African swine fever: apoptosis of lymphocytes and virus replication in other cells, J. Gen. Virol. 76 (1995) 2399-2405.

[9] Gómez-Villamandos J.C., Hervás J., Méndez A., Carrasco L., Villeda C.J., Wilkinson P.J, Sierra M.A., Pathological changes of renal interstitial capillaries in pigs inoculated with two different strains of African swine fever virus, J. Comp. Pathol. 112 (1995) 283-298.

[10] Gómez-Villamandos J.C., Ruiz-Villamor E., Ruíz-Villamor E., Bautista M.J., Quezada M., Sánchez C.P., Sierra M.A., Pathogenesis of Classical swine fever: renal haemorrhages and erythrodiapedesis, J. Comp. Pathol. 123 (2000) 47-54.

[11] Gómez del Moral M., Ortuño E., FernándezZapatero P., Alonso F., Alonso C., Ezquerra A., Domínguez J., African swine fever virus infection induces tumor necrosis factor alpha production: implications in pathogenesis, J. Virol. 73 (1999) 2173-2180.

[12] Haagmans B.L., van den Eertwegh A.J.M., Claasen E., Horzinek M.C., Schijns V.E.C.J., Tumor necrosis factor- $\alpha$ production during 
cytomegalovirus infection in immunosuppressed rats, J. Gen. Virol. 75 (1994) 779-787.

[13] Hsu H., Raine L., Fanger H., Use of avidin-biotinperoxidase complex (ABC) in immunoperoxidase techniques: a comparison between $\mathrm{ABC}$ and unlabeled antibody (PAP) procedures, Histochem. Cytochem. 29 (1981) 577-580.

[14] Huether M., Lin G; Smith D., Murtaugh M., Molitor M., Cloning sequencing and regulation of an mRNA encoding porcine interleukin- $1 \beta$, Gene 129 (1993) 285-289.

[15] Jevinkar A.M., Brennan D.C; Singer G.G., Heng J.E., Malinski W., Wuthrich R.P., Glimcher L.H., Rubin Kelley V.E., Stimulated kidney tubular epithelial cells express membrane associated and secreted TNF $\alpha$, Kidney Int. 40 (1991) 203-211.

[16] Lechner F., Vogt H-R., Seow H.F., Von Bodungen U., Bertoni G., Zurbriggen A., Peterhans E., Expression of TNF- $\alpha$ in arthritis caused by caprine arthritis encephalitis virus, Vet. Immunol. Immunopathol. 54 (1996) 281-289.

[17] Luster M.I., Simeonova P.P., Gallucci R., Matheson J., Tumor necrosis factor $\alpha$ and toxicology, Crit. Rev. Toxicol. 29 (1999) 491-511.

[18] Maliszewski C., Renshaw B., Schoenborn M., Urban J., Baker P., Porcine IL-1 alpha cDNA nucleotide sequence, Nucleic Acids Res. 18 (1990) 4282.

[19] Murtaugh M.P., Porcine cytokines, Vet. Immunol. Immunopathol. 43 (1994) 37-44.

[20] Murtaugh M.P., Baarsch M.J., Zhou Y., Scamurra R.W., Lin G., Inflammatory cytokines in animal health and diseases, Vet. Immunol. Immunopathol. 54 (1996) 45-55.
[21] Pauli U., Porcine TNF: A review, Vet. Immunol. Immunopathol. 47 (1995) 187-201.

[22] Portiansky E.L., Massone A.R., Gimeno E.J., Kinetics of epitope retrieval techniques for unmasking cytokeratins in bovine prostatic tissues after different formaldehyde fixation times, Appl. Immunohistochem. 5 (1997) 194-201.

[23] Sato S., Masuda T., Satoh T., Suzuki K., Immunohistochemical study of tumor necrosis factoralpha in acute liver injury induced by Propionibacterium acnes and lipopolysaccharide in rats, Int. Hepatol. Commun. 6 (1997) 179-190.

[24] Smith R.A., Evaluation of cross-species reactivity of antibodies to human antigens in animal models using immunoperoxidase, J. Histotechnol. 13 (1990) 255-269.

[25] Su X., Prestwood A.K., Otto C.M., Prickett D., Mcgraw R.A., Monoclonal antibodies to porcine tumor necrosis alpha: development of an enzymelinked immunosorbent assay, J. Immunoass. 13 (1992) 253-272.

[26] Van Reeth K., Nauwynck H., Proinflammatory cytokines and viral respiratory diseases in pigs, Vet. Res. 31 (2000) 187-213.

[27] Van Reeth K., Nauwynck H., Pensaert M., Bronchoalveolar Interferon- $\alpha$ Tumor Necrosis Factor- $\alpha$ Interleukin 1 and inflammation during Acute Influenza in Pigs: A possible model for Humans?, J. Infect. Dis. 177 (1988) 1076-1079.

[28] Willeaume V., Kruys V., Mijatovic T., Huez G., Tumor necrosis factor- $\alpha$ production induced by viruses and by lipopolysaccharides in macrophages: similarities and differences, J. Inflamm. 46 (1996) 1-12. 